\section{PERILAKU BULLYING PADA REMAJA DAN FAKTOR-FAKTOR YANG MEMPENGARUHINYA}

Bullying merupakan suatu kejadian yang banyak diberitakan di media cetak maupun elektronik saat ini yang menarik perhatian pendidikan masa kini yang dilakukan siswa kepada siswa lainnya di sekolah bukan hanya di Indonesia tapi hingga diseluruh dunia. Dampak bullying yang dialami adalah kurangnya harga diri, menderita masalah kesehatan mental, dan mempunyai rasa ketakutan. Secara umum, perilaku bullying berdampak negatif oleh kehidupan individu dan akademik siswa dan bahkan ada yang berakhir dengan bunuh diri

Secara garis besar faktor yang berhubungan perilaku bullying menurut Tumon (2014) dan Usman (2013) yaitu faktor keluarga, faktor kepercayaan diri dan teman sebaya. Keluarga yang mengalami masalah dalam keluarga seperti broken home atau kurangnya dukungan dalam keluarga dapat berdampak buruk terutama bagi anak seperti, kurangnya perhatian membuat anak cenderung kurang rasa percaya diri sehingga anak lebih sering menghabiskan waktu bersama teman-temannya diluar. Teman sebaya mempengaruhi bullying karena anak lebih banyak menghabiskan waktu diluar bersama teman-temannya disekolah dan cenderung mengikuti apa yang dilakukan oleh teman sekelompoknya (Saifullah, 2016).

Buku ini merupakan hasil karya dosen Universitas Muhammadiyah Kalimantan Timur yang merupakan keinginan untuk berkontribusi mengembangkan pendidikan pada umumnya dan pada area bidang keperawatan pada khususnya. Buku ini juga dapat menjadi referensi bagi para pembaca khususnya yang konsen pada kesehatan mental.
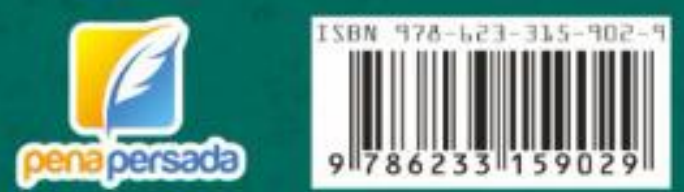

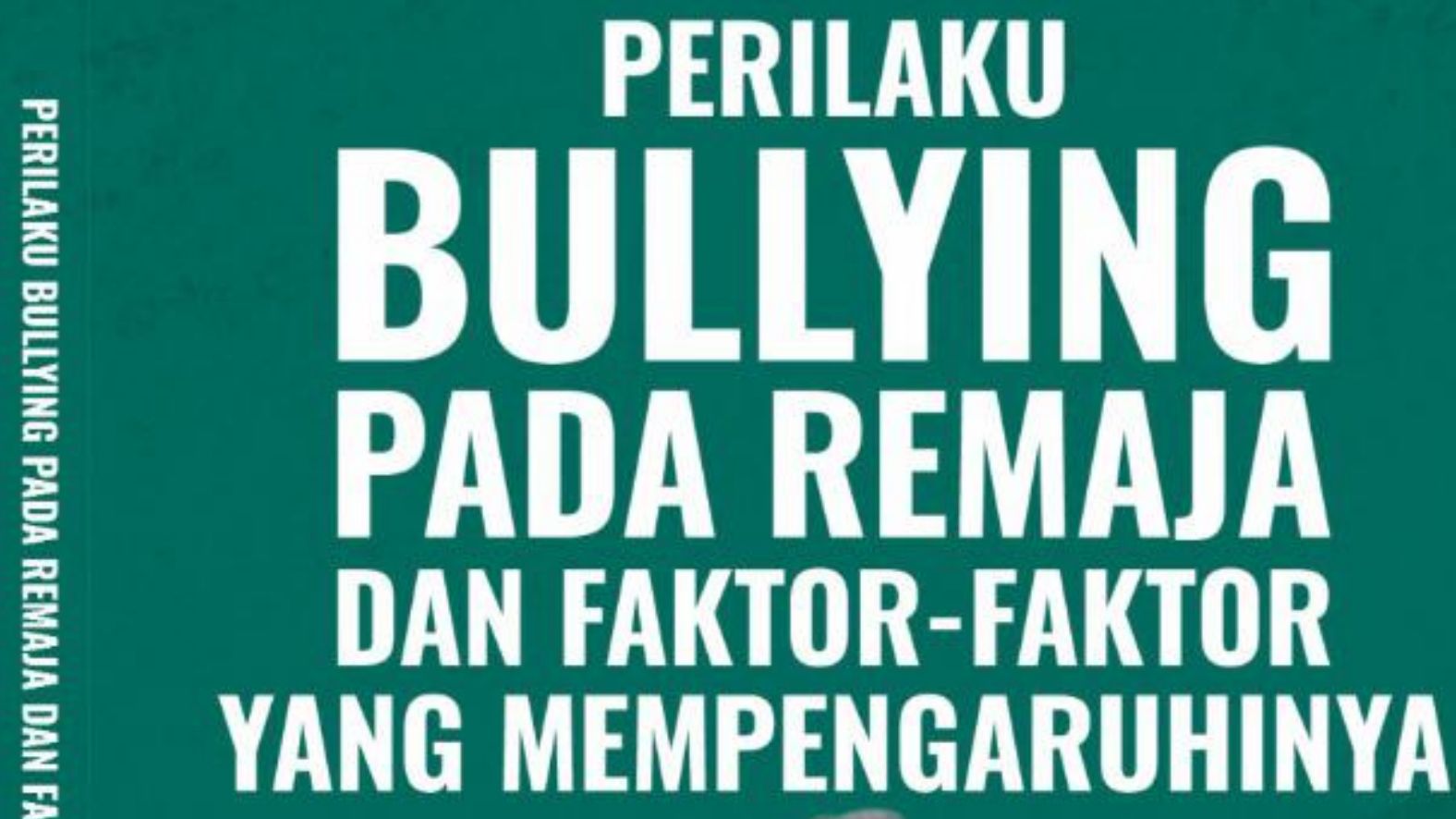

产

Ns. Arief Budiman, M.Kep Ns. Fitroh Asriyadi, M.Kep 


\section{PERILAKU BULLYING PADA REMAJA DAN \\ FAKTOR-FAKTOR YANG MEMPENGARUHINYA}

NS. ARIEF BUDIMAN, M.KEP

NS. FITROH ASRIYADI, M.KEP

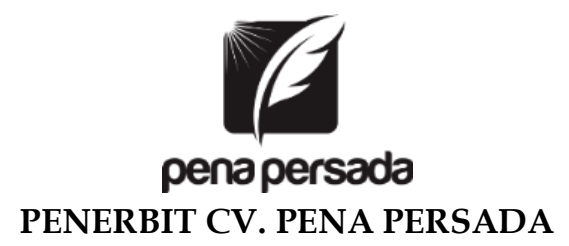




\title{
PERILAKU BULLYING PADA REMAJA DAN \\ FAKTOR-FAKTOR YANG MEMPENGARUHINYA
}

\author{
Penulis: \\ Ns. Arief Budiman, M.Kep \\ Ns. Fitroh Asriyadi, M.Kep \\ ISBN : 978-623-315-902-9 \\ Editor: \\ Fitriani Dwi Ramadhani \\ Design Cover : \\ Retnani Nur Brilliant \\ Layout : \\ Dita Nurul Aviqoh \\ Penerbit CV. Pena Persada \\ Redaksi : \\ Jawa Tengah \\ Email : penerbit.penapersada@gmail.com \\ Anggota IKAPI \\ All right reserved \\ Cetakan pertama : 2021
}

Jl. Gerilya No. 292 Purwokerto Selatan, Kab. Banyumas

Website : penapersada.com Phone : (0281) 7771388

Hak Cipta dilindungi oleh undang-undang. Dilarang memperbanyak karya tulis ini dalam bentuk apapun tanpa izin penerbit 


\section{KATA PENGANTAR}

Puji syukur saya panjatkan kepada Tuhan Yang Maha Esa, karena atas berkat dan rahmat-Nya, saya dapat menyelesaikan buku ini. Penulisan buku merupakan buah karya dari pemikiran penulis yang diberi judul "Faktor-Faktor Yang Berhubungan Dengan Perilaku Bullying Pada Remaja". Saya menyadari bahwa tanpa bantuan dan bimbingan dari berbagai pihak sangatlah sulit bagi saya untuk menyelesaikan karya ini. Oleh karena itu, saya mengucapkan banyak terima kasih pada semua pihak yang telah membantu penyusunan buku ini. Sehingga buku ini bisa hadir di hadapan pembaca.

Kajian dalam buku ini bertujuan untuk mengetahui dan menunjukkan pada distribusi frekuensi pengaruh faktor kepercayaan diri menunjukkan bahwa responden yang pernah atau yang sedang menerima perilaku bullying sebagian besar berusia 14 tahun sebanyak 45 responden dengan presentase $24,9 \%$ pada kategori sangat rendah. Sedangkan pada distribusi frekuensi perilaku bullying menunjukkan mayoritas usia berada pada usia 14 tahun sebanyak 49 responden dengan presentase 27,1\% pada kategori rendah. Selanjutnya dari penelitian yang telah dilakukan pada siswa dan siswi di SMP Negeri 5 Samarinda, menunjukkan jumlah siswa laki-laki sebanyak 79 orang $(43,9 \%)$ dan siswa perempuan sebanyak 102 orang $(56,4 \%)$.

Pada kesempatan ini penulis mengucapkan terima kasih kepada kedua orang tuaku tercinta, Bapak H. Abdul Jalal dan Ibu Hj. Supiah, kemudian kepada tim peneliti Savitri Iska, Sari, Riski Novilia, Redi Oktavianur, Ns. Fitroh Asriyadi, M. Kep juga kepada istri dan anakku tercinta Dwi Pratiwi Amd.Kep dan Aurora Elmeira Budiman sehingga penulis dapat menapakki kehidupan ini dengan penuh hikmah serta dukungan. Semoga kebaikan dan kasih sayang terbalaskan dengan surga-Nya. Amin. 
Penulis menyadari bahwa buku ini masih jauh dari kesempurnaan. Oleh karena itu kritik dan saran yang membangun sangat dibutuhkan guna penyempurnaan buku ini. Akhir kata saya berharap Tuhan Yang Maha Esa berkenan membalas segala kebaikan semua pihak yang telah membantu. Semoga buku ini akan membawa manfaat bagi pengembangan ilmu di bidang kesehatan. 


\section{DAFTAR ISI}

KATA PENGANTAR ….................................................................

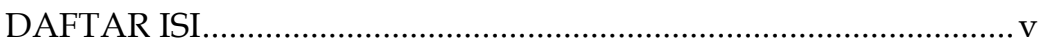

BAB 1 FENOMENA PERILAKU BULLYING …….......................... 1

A. Perilaku Bullying Pada Remaja ...................................... 1

BAB 2 MASA PUBERTAS FAKTOR BULLYING ……………......... 6

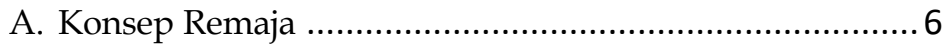

B. Konsep Perilaku............................................................ 7

C. Konsep Bullying.......................................................... 9

D. Faktor - Faktor Yang Mempengaruhi Bullying............. 12

E. Penelitian Terkait ...................................................... 23

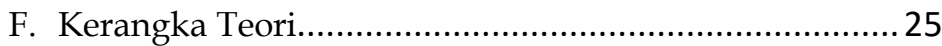

G. Kerangka Konsep .................................................... 26

H. Hipotesis ................................................................... 26

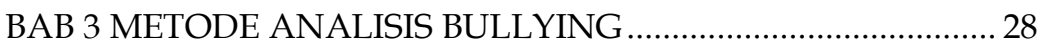

A. Deskripsi Faktor Bullying.................................................... 28

B. Populasi Dan Sampel ....................................................... 28

C. Waktu dan Tempat Penelitian........................................... 31

D. Definisi Operasional ............................................................ 31

E. Variabel Penelitian............................................................. 33

F. Instrument Penelitian .......................................................... 33

G. Validitas dan Reliabilitas ..................................................... 37

H. Teknik Pengumpulan Data ................................................. 41

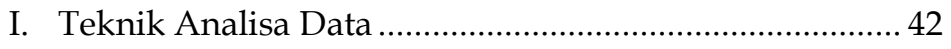

J. Analisis Uniariat dan Bivariat ............................................ 43

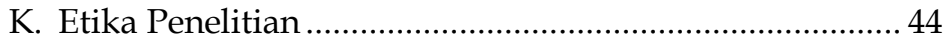

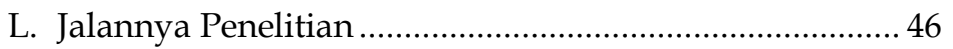

M. Jadwal Penelitian ............................................................... 47 
BAB 4 HASIL ANALISIS FAKTOR BULLYING .48

A. Hasil Kajian................................................................. 48

B. Hasil Univariat............................................................ 49

C. Diskusi Dalam Kajian.................................................... 53

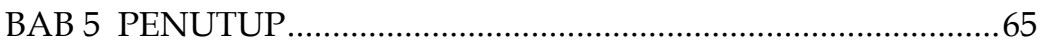




\section{BAB 1 \\ FENOMENA PERILAKU BULLYING}

\section{A. Perilaku Bullying Pada Remaja}

Fenomena perilaku bullying merupakan bagian dari kenakalan remaja yang sering di ketahui terjadi pada masa masa remaja, dikarenakan masa ini remaja memiliki egosentrisme yang tinggi. Masa remaja merupakan suatu fase perkembangan antara masa kanak - kanak dan masa dewasa, usia peserta didik / remaja sekitar 12-18 tahun. Usia rentan menjadi korban bullying menurut Sejiwa (2008) adalah usia remaja yaitu sekitar 13-18 tahun, dimana dalam periode tersebut dianggap sebagai masa yang sangat penting dalam kehidupan seseorang khususnya dalam pembentukan kepribadian. Sehingga sebelum memasuki usia remaja, seorang anak harus dibekali pengetahuan serta pemahaman terkait bahaya tindakan bullying pada usia sekolah dasar.

Bullying sendiri paling banyak terjadi pada siswa Sekolah Menengah Pertama (SMP) yakni siswa usia 13 hingga 14 tahun. Anak usia 12-17 tahun dilaporkan 84 \% nya mengalami bullying (Tribunjogja, 2017). Hal ini juga ditegaskan oleh Liu dan Grave (2011) bullying dapat terjadi pada semua tingkat usia, tetapi mulai meningkat pada akhir sekolah dasar, puncak di sekolah menengah, dan umumnya menurun di sekolah tinggi.

Pada masa Sekolah Menengah Pertama (SMP), remaja memiliki perkembangan emosi, sosial, fisik dan psikis. Remaja juga merupakan tahapan perkembangan yang harus dilewati dengan berbagai kesulitan. Pada masa ini juga, kondisi psikis remaja sangat labil. Karena masa ini merupakan fase pencarian jati diri. Biasanya mereka selalu ingin tahu dan mencoba sesuatu yang baru dilihat atau diketahui dari lingkungan sekitarnya, mulai lingkungan keluarga, sekolah, teman sepermainan dan masyarakat (Trevi, 2010). 
Bullying merupakan tindakan kekerasan secara fisik maupun verbal, dimana si pelaku merendahkan dan mengintimidasi korban agar tak bisa melawan, pelaku bullying mencari kesenangan yang tak bisa didapatkannya dan melampiaskan nya dengan membuat orang lain menderita. Dampak bullying akan menghambat anak dalam mengaktualisasi dirinya karena perilaku bullying tidak akan memberi rasa aman dan nyaman, dan akan membuat para korban bullying merasa takut dan terintimidasi, rendah diri, tak berharga, sulit berkonsentrasi dalam belajar, serta tidak mampu untuk bersosialisasi dengan lingkungannya (Sejiwa, 2008). Secara garis besar faktor yang berhubungan perilaku bullying menurut Tumon (2014) dan Usman (2013) yaitu faktor keluarga, faktor kepercayaan diri dan teman sebay. Keluarga yang mengalami masalah dalam keluarga seperti broken home atau kurangnya dukungan dalam keluarga dapat berdampak buruk terutama bagi anak seperti, kurangnya perhatian membuat anak cenderung kurang rasa percaya diri sehingga anak lebih sering menghabiskan waktu bersama teman- temannya diluar. Teman sebaya mempengaruhi bullying karena anak lebih banyak menghabiskan waktu diluar bersama teman-temannya disekolah dan cenderung mengikuti apa yang dilakukan oleh teman sekelompoknya (Saifullah, 2016).

Salah satu fenomena yang menyita perhatian di dunia pendidikan zaman sekarang adalah kekerasan di sekolah, baik yang dilakukan oleh guru terhadap siswa, maupun oleh siswa terhadap siswa lainnya. Maraknya aksi tawuran dan kekerasan (bullying) yang dilakukan oleh siswa di sekolah yang semakin banyak menghiasi deretan berita di halaman media cetak maupun elektronika menjadi bukti telah tercabutnya nilai-nilai kemanusiaan. (Wiyani, 2012).

Indonesia saat ini menduduki peringkat kedua terbesar setelah Jepang pada kasus bullying atau kekerasan terhadap anak di sekolah (Indra, 2015). Data Global School-based Student Health Survey (GSHS) menunjukkan bahwa grafik kasus bullying di Indonesia mengalami peningkatan sejak tahun 2007, 
sekitar 40\% murid berusia 13-15 tahun di Indonesia melaporkan telah diserang secara fisik selama 12 bulan terakhir di sekolah mereka. Laporan Komisi Perlindungan Anak Indonesia (KPAI) terbaru tahun 2013 menunjukkan bahwa terdapat 1.051 anak menjadi korban kekerasan di Indonesia dan 70\% anak-anak usia 8 - 12 pernah menjadi pelaku kekerasan atau bullying di sekolah. KPAI menemukan bahwa anak mengalami bullying di lingkungan sekolah sebesar (87.6\%). Dari angka (87.6\%) tersebut, (29.9\%) bullying dilakukan oleh guru, (42.1\%) dilakukan oleh teman sekelas, dan $(28.0 \%)$ dilakukan oleh teman kelas lain (Prima, 2012). Komisi Perlindungan Anak Indonesia (KPAI) tahun 2014 mencatat bahwa dari total pengaduan bullying, yang terjadi di bidang pendidikan sebanyak 1.480 kasus. Bullying yang disebut KPAI sebagai bentuk kekerasan di sekolah, mengalahkan tawuran pelajar, diskriminasi pendidikan ataupun aduan pungutan liar (Republika, 2014).

Upaya pemerintah dalam menanggulangi kasus bullying pemerintah sudah menerbitkan Undang-Undang Nomor 35 tahun 2014 tentang perubahan pertama atas Undang-Undang Nomor 23 Tahun 2002 tentang Perlindungan Anak. Kementerian Pemberdayaan Perlindungan Perempuan dan Perlindungan anak (PPPA) juga sudah berkoordinasi dengan kepolisian dan kejaksaan agar hukuman pelaku kekerasan terhadap anak disa diberikan sebarat-beratnya. Hukuman berat berat itu sesuai tindakan pelaku, sehingga diharapkan menimbulkan efek jera bagi pelaku kekerasan (Berita Satu, 2016).

Semua pihak baik di lingkungan keluarga, masyarakat dan sekolah. Salah satu yang dilakukan United Nations Children's Fund (UNICEF) Pusat selama dua atau tiga tahun ini adalah mengembangkan riset aksi program model pencegahan bullying di sekolah pada dua daerah, yaitu Provinsi Sulawesi Selatan dan Provinsi Jawa Tengah. Metode pendekatan yang digunakan bernama roots, yaitu model pendekatan program global pencegahan kekerasan di kalangan teman sebaya yang berfokus pada upaya membangun iklim yang aman di sekolah dengan mengaktivasi peran siswa sebagai agen berpengaruh 
atau agen perubahan. Program tersebut diharapkan dapat menghasilkan model pengembangan upaya pencegahan perlindungan anak yang mampu bekerja secara holistik dan komprehensif, apabila sudah berjalan dengan baik akan direplikasi didaerah lain (Portal Resmi Provinsi Jawa Tengah, 2018).

Kalimantan Timur sebagai salah satu provinsi di Indonesia berdasarkan laporan Badan Pemberdayaan Perempuan dan Keluarga Berencana (BPPKB) Provinsi menunjukkan bahwa terdapat 457 kasus pelecehan seksual dan kekerasan pada anak, dan diantaranya juga terdapat kasus bullying atau intimidasi, sepanjang tahun 2015 lalu. Penelitian yang dilakukan oleh Amrina (2014) menjelaskan bahwa 23\% siswa SMPN 31 Samarinda memiliki tingkat bullying tinggi, 39\% tingkat bullying sedang.

Penelitian Akbar (2013) pada kasus bullying yang sama terjadi di SMPN 5 Samarinda, para pelakunya banyak dilakukan oleh siswa laki- laki dan sebagian dilakukan oleh siswa perempuan. hal ini senada dengan penelitian yang dilakukan oleh Adilla (2009) dalam jurnalnya yang menyimpulkan bahwa pelajar laki-laki lebih sering menggunakan tindakan bullying terhadap pelajar lain baik secara langsung maupun tidak langsung dibandingkan dengan pelajar perempuan. Dari beberapa bentuk perilaku bullying yang dilakukan antarsiswa di SMP N

5 Samarinda, yang paling sering terjadi ialah penghinaan terhadap perilaku maupun fisik dari korbannya dan sedikit sekali perlakuan kekerasan yang diberikan kepada korbannya berupa kekerasan fisik.

Berdasarkan studi pendahuluan yang telah dilakukan oleh peneliti di SMP 5 Samarinda, dilakukan wawancara terhadap Guru BK dan mengatakan di dapatkan 4 siswa yang sering mengganggu teman maupun kakak kelas, kejadian barubaru ini terjadi pada saat olahraga salah satu siswa suka menjegal temannya saat berlari. Salah satu Alumni SMP Negeri 5 Samarinda juga mengatakan ia bersama teman sekelompok 
(geng) pernah menjadi pelaku bully terhadap adik kelas seperti memalak dan mengejek. Bullying merupakan tindakan agresivitas antar siswa yang memiliki dampak paling negatif bagi korbannya. Oleh karena itu sekiranya mulai dari sekarang dan untuk seterusnya masyarakat dapat menyadari bahwa dengan membiarkan atau menerima perilaku bullying pada lingkungan sosial, berarti memberikan bullies power kepada pelaku bullying itu sendiri dan menciptakan interaksi sosial yang tidak sehat serta meningkatkan budaya kekerasan.

Terutama lingkungan sekolah diharapkan dapat menerapkan peraturan yang ada secara tegas dan konsisten kepada setiap siswa-siswi di sekolah serta melakukan pengawasan yang serius. Kemudian sekolah juga berupaya untuk mengoptimalkan fungsi unit BK (bimbingan konseling), terutama agar masalah dan penanganannya terhadap korban tindakan perilaku bullying dapat ditindak lanjuti secara tepat. Karena itu penelitian ini sangat penting untuk diteliti. Berdasarkan fenomena diatas oleh karena itu peneliti tertarik ingin melakukan penelitian "Faktor-faktor yang Berhubungan dengan Perilaku Bullying pada Remaja di SMP Negeri 5 Samarinda". 


\section{BAB 2 \\ MASA PUBERTAS FAKTOR BULLYING}

\section{A. Konsep Remaja}

Menurut Organisasi Kesehatan Dunia (WHO), remaja (adolescence) adalah mereka yang berusia 10-19 tahun sebagai suatu masa dimana individu berkembang dari saat pertama kali ia menunjukkan tanda-tanda seksual sekundernya (pubertas) sampai saat ia mencapai kematangan seksual. Sementara Perserikatan Bangsa-Bangsa (PBB) menyebutkan anak muda untuk usia 15-24 tahun. Ini kemudian disatukan dalam terminologi kaum muda (young people) yang mencakup usia 1024 tahun (WHO, 2013).

Menurut Santrock (2011) masa remaja adalah suatu periode transisi dalam rentang kehidupan manusia, yang menjembatani masa kanak-kanak dengan masa dewasa. Menurut Hurlock (2015) awal masa remaja berlangsung kira-kira dari 13 tahun sampai 16 tahun atau 17 tahun, dan akhir masa remaja bermula dari usia 16 atau 17 tahun sampai 18 tahun, yaitu usia matang secara hukum. Adapun ciri-ciri masa remaja yang membedakan dengan periode sebelum dan sesudahnya, yaitu masa remaja sebagai periode yang penting, periode peralihan, periode perubahan, usia bermasalah, remaja sebagai masa mencari identitas, usia yang menimbulkan ketakutan, masa yang tidak realistis, dan masa remaja sebagai ambang masa dewasa.

Salah satu ciri menyebutkan bahwa remaja adalah usia bermasalah, dimana masalah masa remaja sering menjadi masalah yang sulit diatasi baik oleh anak laki-laki maupun anak perempuan. Ada dua alasan bagi kesulitan itu. Pertama, sepanjang masa kanak-kanak sebagian masalah anak-anak diselesaikan oleh orang tua dan guru-guru, sehingga kebanyakan remaja tidak berpengalaman dalam mengatasi masalah itu. Kedua, karena para remaja merasa mandiri sehingga ingin mengatasi masalahnya sendiri dan menolak bantuan orang tua dan guru-guru (Hurlock, 2015). 
Berbagai masalah yang dihadapi oleh remaja salah satunya adalah kasus kekerasan atau agresivitas baik oleh guru terhadap siswa, maupun antar sesama siswa sendiri. Kekerasan yang ditemui tersebut tak hanya secara fisik namun juga secara psikologis. Kekerasan yang dilakukan oleh pihak yang merasa diri lebih berkuasa atas pihak yang dianggap lebih lemah disebut dengan bullying (Magfirah \& Rachmawati, 2009).

Dampak yang diakibatkan oleh tindakan ini pun sangat luas cakupannya. Remaja yang menjadi korban bullying lebih berisiko mengalami berbagai masalah kesehatan, baik secara fisik maupun mental. Adapun masalah yang lebih mungkin diderita anak-anak yang menjadi korban bullying, antara lain munculnya berbagai masalah mental seperti depresi, kegelisahan dan masalah tidur yang mungkin akan terbawa hingga dewasa, keluhan kesehatan fisik, seperti sakit kepala, sakit perut dan ketegangan otot, rasa tidak aman saat berada di lingkungan sekolah, dan penurunan semangat belajar dan prestasi akademis.

\section{B. Konsep Perilaku}

Perilaku adalah segenap manifestasi hayati individu dalam berinteraksi dengan lingkungan, mulai dari perilaku yang paling nampak sampai yang tidak tampak, dari yang dirasakan sampai paling yang tidak dirasakan (Okviana, 2015). Perilaku merupakan hasil daripada segala macam pengalaman serta interaksi manusia dengan lingkunganya yang terwujud dalam bentuk pengetahuan, sikap dan tindakan. Perilaku merupakan respon/reaksi seorang individu terhadap stimulus yang berasal dari luar maupun dari dalam dirinya (Notoatmojo, 2010). Sedangkan menurut Wawan (2011) Perilaku merupakan suatu tindakan yang dapat diamati dan mempunyai frekuensi spesifik, durasi dan tujuan baik disadari maupun tidak. Perilaku adalah kumpulan berbagai faktor yang saling berinteraksi. Jenis-jenis pengukuran perilaku ada beberapa teknik, yaitu : Skala Likert Penggunaan skala Likert menurut Sugiyono (2013) adalah skala Likert digunakan untuk mengukur sikap, pendapat dan persepsi seseorang atau sekelompok orang tentang fenomena sosial. 


\section{Skala Thurstone}

Skala Thurstone merupakan salah satu skala sikap yang disusun dengan memilih butir yang berbentuk skala interval. Setiap butir memiliki kunci skor dan jika disusun, kunci skor menghasilkan nilai yang berjarak sama. Skala Thurstone dibuat dalam bentuk sejumlah (40-50) pernyataan yang relevan dengan variable yang hendak diukur kemudian sejumlah ahli (20-40) orang menilai relevansi pernyataan itu dengan konten atau konstruk yang hendak diukur.

Skala Thurstone meminta responden untuk memilih pertanyaan yang ia setujui dari beberapa pernyataan yang menyajikan pandangan yang berbeda-beda. Metode pengukuran ini dikembangkan untuk menilai secara spesifik terhadap objek atau subjek yang hendak diteliti (Sugiyono, 2009).

2. Skala Guttman

Perilaku dapat diukur dengan menggunakan teknik skala Guttman. Skala ini merupakan skala yang bersifat tegas dan konsisten dengan memberikan jawaban yang tegas seperti jawaban dari pertanyaan/pernyataan: ya dan tidak, positif dan negatif, setuju dan tidak setuju, benar dan salah. Skala guttman ini pada umumnya dibuat seperti cheklist dengan interpretasi penilaian, apabila skor benar nilainya 1 dan apabila salah nilainya 0 dan analisanya dapat dilakukan seperti skala likert (Aziz, 2007).

3. Skala Semantic Defferential

Semantic differential adalah salah satu bentuk instrumen pengukuran yang berbentuk skala, yang dikembangkan oleh Osgood, Suci, dan Tannenbaum (1984). Instrumen ini juga digunakan untuk mengukur reaksi terhadap stimulus, kata-kata, dan konsep-konsep dan dapat disesuaikan untuk orang dewasa atau anak-anak dari budaya manapun juga. Skala ini juga di gunakan untuk mengukur sikap, hanya bentuknya tidak pilihan ganda maupun checklist, tetapi tersusun dalam satu garis kontinum yang jawaban "sangat positifnya" terletak di bagian kanan garis, 
dan jawaban yang "sangat negatif" terletak di bagian kiri garis, atau sebaliknya. Data yang di peroleh adalah daya interval, dan biasanya skala ini di gunakan untuk mengukur sikap/karakteristik tertentu yang di punyai oleh seseorang (Heise, 2006)

4. Skala Rating

Skala rating adalah data mentah yang diperoleh berupa angka kemudian ditafsirkan dalam pengertian kualitatif. Dalam skala model rating scale, responden tidak akan menjawab salah satu dari jawaban kualitatif yang telah disediakan, tapi menjawab salah satu jawaban kuantitatif yang telah disediakan. Oleh karena itu, rating scale ini lebih fleksibel, tidak terbatas pengukuran sikap saja tetapi bisa juga mengukur persepsi responden terhadap fenomena (Sugiyono, 2009).

\section{Konsep Bullying}

1. Pengertian Bullying

Bullying adalah perilaku agresif yang dapat terjadi di kalangan anak terutama anak usia sekolah dan melibatkan ketidakseimbangan kekuatan yang berpotensi untuk dilakukan secara berulang- ulang (Control Disease Center: National Center for Injury Prevention and Control, 2014). Bullying merupakan bentuk agresivitas yang dilakukan oleh satu individu maupun secara berkelompok terhadap individu atau kelompok lain dengan tujuan untuk mendominasi (dominate), menyakiti (hurt), atau mengasingkan pihak lain (exclude another) (Praningtyas, 2010). Bullying adalah perilaku agresif yang dilakukan oleh seseorang atau kelompok terhadap orang-orang atau kelompok lain yang dilakukan secara berulang-ulang dengan cara menyakiti secara fisik maupun mental (Prasetyo, 2011). Kata bullying berasal dari bahasa Inggris, yaitu dari kata bull yang berarti banteng yang senang merunduk kesana kemari. Dalam bahasa Indonesia, secara etimologi kata bully berarti penggertak, orang yang mengganggu orang lemah. Kemudian, Olweus juga mengatakan hal yang serupa bahwa 
bullying merupakan perilaku negatif yang mengakibatkan seseorang ada dalam keadaan tidak nyaman/terluka dan biasanya terjadi berulang-ulang. (Wiyani, 2012).

Definisi bullying sendiri, menurut Komisi Nasional Perlindungan Anak adalah kekerasan fisik dan psikologis berjangka panjang yang dapat dilakukan seseorang atau kelompok terhadap seseorang yang tidak mampu mempertahankan diri (Tiga Ananda, 2015). Dapat dikatakan pula bullying adalah tindakan yang dilakukan seseorang secara sengaja membuat orang lain takut atau terancam sehingga menyebabkan korban merasa takut, terancam, atau setidak-tidaknya tidak bahagia (Saifullah, 2016).

Dari penjelasan diatas dapat disimpulkan bahwa bullying merupakan suatu tindakan kekerasan baik secara fisik maupun mental yang dilakukan oleh individu maupun secara berkelompok yang dapat menyebabkan trauma secara fisik maupun mental. Biasanya bully yang sering terjadi adalah seperti mengejek dan memalak dikalangan anak usia sekolah.

2. Bentuk - Bentuk Bullying

Menurut Wiyani (2012) disebutkan bahwa terdapat empat bentuk bullying, yaitu:

a. Lisan, misalnya memberi julukan, menggoda, mengejek, menghina, mengancam.

b. Fisik, misalnya memukul, menendang, menyelengkat.

c. Sosial, misalnya mengabaikan, tidak mengajak berteman, memberi isyarat yang tidak sopan.

d. Psikologis, misalnya menyebarkan desas-desus, 'dirty looks' (pandangan yang menunjukkan rasa tidak senang, kebencian atau kemarahan), menyembunyikan atau merusak barang, pesan jahat lewat SMS dan email, penggunaan ponsel kamera yang tidak patut. 
Menurut Bauman (2008), tipe-tipe bullying adalah sebagai berikut :

a. Overt bullying (Intimidasi terbuka), meliputi bullying secara fisik dan secara verbal, misalnya dengan mendorong hingga jatuh, memukul, mendorong dengan kasar, memberi julukan nama, mengancam dan mengejek dengan tujuan untuk menyakiti.

b. Indirect bullying (Intimidasi tidak langsung) meliputi agresi relasional, dimana bahaya yang ditimbulkan oleh pelaku bullying dengan cara menghancurkan hubunganhubungan yang dimiliki oleh korban, termasuk upaya pengucilan, menyebarkan gosip, dan meminta pujian atau suatu tindakan tertentu dari kompensasi persahabatan. Bullying dengan cara tidak langsung sering dianggap tidak terlalu berbahaya jika dibandingkan dengan bullying secara fisik, dimaknakan sebagai cara bergurau antar teman saja. Padahal hubungan bullying lebih kuat terkait dengan distress emosional daripada bullying secara fisik. Bullying secara fisik akan semakin berkurang ketika siswa menjadi lebih dewasa tetapi bullying yang sifatnya merusak hubungan akan terus terjadi hingga usia dewasa.

3. Cyberbullying (Intimidasi melalui dunia maya), seiring dengan perkembangan dibidang teknologi, siswa memiliki media baru untuk melakukan bullying, yaitu melalui sms, telepon maupun internet. Cyberbullying melibatkan penggunaan teknologi informasi dan komunikasi, seperti email, telepon seluler dan peger, sms, website pribadi yang menghancurkan reputasi seseorang, survei di website pribadi yang merusak reputasi orang lain, yang dimaksudkan adalah untuk mendukung perilaku menyerang seseorang atau sekelompok orang, yang ditujukan untuk menyakiti orang lain, secara berulang- ulang kali. 
4. Dampak - Dampak Bullying

Menurut Wiyani (2012) dampak yang dialami korban bullying adalah mengalami berbagai macam gangguan yang meliputi kesejahteraan psikologis yang rendah (Low Psicological Wellbeing) di mana korban akan merasa tidak nyaman, takut, rendah diri, serta tidak berharga, penyesuaian sosial yang buruk dimana korban merasa takut ke sekolah bahkan tidak mau sekolah, menarik diri dari pergaulan, prestasi akademik yang menurun karena mengalami kesulitan berkonsentrasi dalam belajar, bahkan berkeinginan untuk bunuh diri dari pada harus menghadapi tekanantekanan berupa hinaan dan hukuman.

Menurut Priyatna (2010) dampak dari bullying yaitu depresi, cemas, selalu khawatir pada masalah keselamatan, menjadi pemurung, agresi, timbul isu-isu akademik, tampak rendah diri dan menjadi pemalu, menarik diri dari pergaulan dan penyalahgunaan substansi (obat atau alkohol). Menurut Dwipayanti dan Komang (2014) anak sebagai korban bullying akan mengalami gangguan psikologis dan fisik, lebih sering mengalami kesepian, dan mengalami kesulitan dalam mendapatkan teman, sedangkan anak sebagai pelaku bullying cenderung memiliki nilai yang rendah. Menurut penelitian Duke University yang diterbitkan 12 Mei 2014 dalam Proceedings of the National Academy of Sciences dampak bullying di masa kanak- kanak dapat berbekas seumur hidup, baik bagi korban maupun pelaku bullying itu sendiri, begitu pula pada kaum dewasa muda yang menunjukkan dampak jangka panjang akibat tindakan bullying. Namun, pelaku bullying didapatkan lebih sehat dibandingkan dengan korban bullying (Liputan6, 2014).

\section{Faktor - Faktor Yang Mempengaruhi Bullying}

Menurut Tumon (2014) dan Usman (2013) faktor yang dapat mempengaruhi Bullying adalah :

1. Faktor Keluarga

Keluarga adalah kelompok orang yang ada hubungan darah atau perkawinan. Orang-orang yang termasuk 
keluarga adalah ibu, bapak, dan anak-anaknya. Ini disebut keluarga batih (nuclear family). Keluarga yang diperluas (extended family) mencakup semua orang dari suatu keturunan dari kakek dan nenek yang sama, termasuk keturunan suami dan isteri. Keluarga mempunyai fungsi untuk berkembang biak, mensosialisasi, mendidik anak, dan menolong serta melindungi yang lemah, khususnya orang tua yang telah lanjut usia (Setiono, 2011).

Dukungan sosial diartikan sebagai sumber emosi, informasi atau pendampingan yang diberikan oleh orangorang di sekitar individu untuk menghadapi setiap permasalahan dan krisis yang terjadi sehari-hari dalam kehidupan (Kail dan Cavanaugh, 2000). Taylor (2009) juga mendefinisikan dukungan sosial sebagai informasi dari orang lain bahwa ia dicintai dan diperhatikan, memiliki harga diri dan bernilai, serta merupakan bagian dari jaringan komunikasi dan kewajiban bersama. Hal yang senada diungkapkan oleh Kenrick, Neuberg, dan Cialdini, (2010) bahwa dukungan sosial adalah dukungan emosi, materi atau informasi yang disediakan orang lain dan bertujuan untuk membantu seseorang. Menurut Baron dan Byrne (2009), dukungan sosial adalah kenyamanan fisik dan psikologis yang disediakan oleh teman dan anggota keluarga. Dukungan keluarga merupakan bagian dari dukungan sosial karena salah satu sumber dukungan sosial adalah keluarga (Dalton, Elias, dan Wandersman, 2007).

Dukungan keluarga menurut Friedman (2010) adalah sebuah proses yang terjadi sepanjang masa kehidupan, sifat dan jenis dukungan berbeda dalam berbagai tahap-tahap siklus kehidupan. Dukungan keluarga dapat berupa dukungan sosial internal, seperti dukungan dari suami, istri atau dukungan dari saudara kandung dan dapat juga berupa dukungan keluarga eksternal bagi keluarga inti. Dukungan keluarga membuat keluarga mampu berfungsi dengan berbagai kepandaian dan akal. Sebagai akibatnya, hal ini meningkatkan kesehatan dan adaptasi keluarga (Friedman, 